$\begin{array}{ll}\text { Received } & : 21 \text { March } 2019 \\ \text { Revised } & : \text { 13 June } 2019 \\ \text { Accepted } & : \text { 22 June } 2019 \\ \text { Published } & : \text { 30 June } 2019\end{array}$

\title{
Politics of Language in Indonesia (1975-2015): Study of History and Language Policy
}

\author{
Sudaryanto $^{1, a)}$, Soeparno ${ }^{1)}$, Lilis Ferawati ${ }^{1)}$ \\ ${ }^{1}$ Universitas Ahmad Dahlan \\ Jalan Kapas Nomor 9 Semaki, Kecamatan Umbulharjo, Kota Yogyakarta, Daerah \\ Istimewa Yogyakarta 55166 \\ E-mail: a) sudaryanto@pbsi.uad.ac.id
}

\begin{abstract}
Indonesia has a political concept of language that is always updated in a certain period of time. The concept was born from a scientific meeting entitled "Seminar Politik Bahasa Nasional" (1975), "Seminar Politik Bahasa" (1999) and finally, "Seminar Politik Bahasa" (2015). Each scientific meeting produces a concept of language politics that is complementary and updates the previous concept. Furthermore, the concept of language politics is closely related to the implementation of a language policy in Indonesia. The research method used is content analysis. The data sources used are books, document archives, and photographs that record language political events over a period of 40 years. The results of this study indicate that (1) the concept of national language politics in the version of the Seminar Politik Bahasa Nasional (1975) focuses more on aspects of Indonesian, regional languages, and foreign languages; the political concept of the national language version of the Seminar Politik Bahasa (1999) focuses more on aspects of Indonesian language and literature, regional language and literature, and foreign languages, and the national language politics version of the Seminar Politik Bahasa (2015) emphasizes improving the function of Indonesian language into an international language; and (2) the political concept of national language 1975 and 1999 language politics became the elaboration of Pasal 36 UUD 1945 and the 2015 political concept of language became the elaboration of UU No. 24 Tahun 2009 and PP No. 57 Tahun 2014.
\end{abstract}

Keywords: language politics, language policy, national language

\begin{abstract}
Abstrak
Indonesia telah memiliki konsep politik bahasa yang selalu diperbaharui dalam kurun waktu tertentu. Konsep tersebut lahir dari pertemuan ilmiah yang diberi tajuk "Seminar Politik Bahasa Nasional" (1975), "Seminar Politik Bahasa" (1999) dan terakhir,
\end{abstract}


"Seminar Politik Bahasa" (2015). Tiap-tiap pertemuan ilmiah itu menghasilkan konsep politik bahasa yang sifatnya melengkapi dan memutakhirkan konsep sebelumnya. Selanjutnya, konsep politik bahasa tadi berkaitan erat dengan pelaksanaan sebuah kebijakan bahasa di Indonesia. Metode penelitian yang digunakan ialah analisis konten. Sumber data yang digunakan ialah buku, arsip dokumen, dan foto yang merekam peristiwa politik bahasa selama kurun waktu 40 tahun. Hasil penelitian ini menunjukkan bahwa (1) konsep politik bahasa nasional versi Seminar Politik Bahasa Nasional (1975) lebih menitikberatkan aspek bahasa Indonesia, bahasa daerah, dan bahasa asing; konsep politik bahasa nasional versi Seminar Politik Bahasa (1999) lebih menitikberatkan aspek bahasa dan sastra Indonesia, bahasa dan sastra daerah, dan bahasa asing, dan konsep politik bahasa nasional versi Seminar Politik Bahasa (2015) lebih menitikberatkan peningkatan fungsi bahasa Indonesia menjadi bahasa internasional; dan (2) konsep politik bahasa nasional 1975 dan politik bahasa 1999 menjadi penjabaran dari Pasal 36 UUD 1945 dan konsep politik bahasa 2015 menjadi penjabaran dari UU No. 24 Tahun 2009 sekaligus PP No. 57 Tahun 2014.

Kata kunci: politik bahasa, kebijakan bahasa, bahasa nasional

\section{PENDAHULUAN}

Bahasa dan sastra Indonesia adalah rumah keindonesiaan kita. Kalimat Suminto A. Sayuti, sastrawan dan guru besar Fakultas Bahasa dan Seni Universitas Negeri Yogyakarta itu, tampaknya tepat saat dikutip untuk membincangkan bahasa Indonesia sebagai identitas keindonesiaan kita. Menurut KBBI Daring (2016), keindonesiaan bermakna 'perihal Indonesia; yang bersangkut paut dengan Indonesia'. Dengan begitu, perihal Indonesia atau yang bersangkut paut dengan Indonesia dapat diketahui atau diakses melalui bahasa dan sastra Indonesia.

Artikel ini menyoroti persoalan politik bahasa di Indonesia dalam kurun waktu 40 tahun (1975-2015). Dalam rentang waktu 40 tahun itu, tak terhindarkan adanya dinamika konsep politik bahasa dari masa tertentu hingga masa tertentu. Sebagai contoh, pada tahun 1975, diselenggarakan Seminar Politik Bahasa Nasional (SPBN) di Jakarta (Halim, 1984b). Berkat seminar itu, muncullah konsep Politik Bahasa Nasional yang menitikberatkan aspek bahasa Indonesia, bahasa daerah, dan bahasa asing dan termuat dalam buku Politik Bahasa Nasional 2. Sayangnya, konsep politik bahasa SPBN (1975) tidak menyentuh sama sekali aspek sastra Indonesia dan sastra daerah.

Selanjutnya, konsep politik bahasa SPBN (1975) direvisi pada saat Seminar Politik Bahasa tahun 1999 di Cisarua, Bogor, dan menghasilkan konsep politik bahasa yang mencakup aspek-aspek sebagi berikut:

(a) bahasa dan sastra Indonesia,

(b) bahasa dan sastra daerah, dan

(c) bahasa asing

Hal ini sebagaimana termuat dalam buku Politik Bahasa: Risalah Seminar Politik Bahasa (Alwi \& Sugono, 2011; Alwi, 2000). 


\section{Gambar 1. Buku Politik Bahasa Nasional 2}

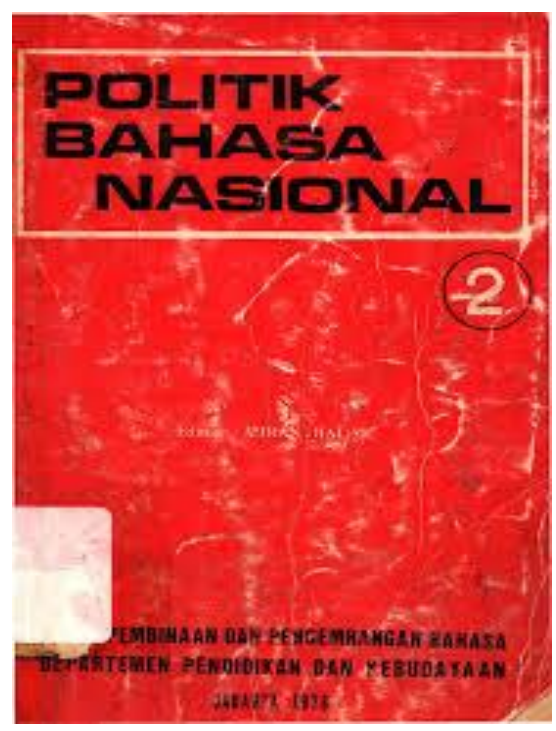

\section{Gambar 2. Buku Politik Bahasa: Risalah Seminar Politik Bahasa}

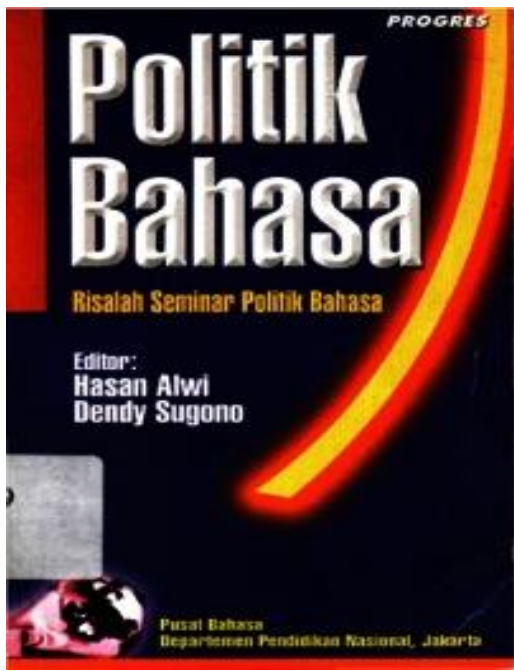

Contoh dinamika konsep politik bahasa di atas sesungguhnya menarik dan layak diketahui oleh masyarakat Indonesia. Paling tidak, masyarakat pendidikan tinggi di Indonesia, dalam hal ini dosen pengampu mata kuliah umum (MKU) Bahasa Indonesia dan mahasiswanya, perlu mengetahui ihwal konsep politik bahasa. Adapun pengertian politik bahasa adalah prinsip-prinsip dan langkah-langkah pelaksanaan pembinaan dan pengembangan bahasa yang dirumuskan sesuai dengan kepentingan nasional suatu negara (Kridalaksana, 2011). Sumber lainnya menyebutkan bahwa politik bahasa nasional adalah kebijakan nasional yang berisi perencanaan, pengarahan, dan ketentuan yang dapat dipakai sebagai dasar bagi pengolahan keseluruhan masalah bahasa (Sudaryanto, 2017).

Kajian-kajian tentang bahasa Indonesia dalam perspektif kebijakan bahasa dan pembelajaran bahasa telah dilakukan oleh sejumlah pakar, seperti Dardjowidjojo 
(1998), Jalal (2001), Abdullah (2003), Santoso (2008), Pastika (2012), Assapari (2014), Aziz (2014), Sartini (2014), Rahayu (2015), Muqri, dkk. (2016), Sudrama, dkk. (2017), Sihombing dkk. (2017), Tilaar (2017), Mulyana (2018), Mutmainah (2018), Suhartatik (2018), Purwahida (2018), Wahyuni (2018), dan Wijana (2018). Ketujuh belas kajian tersebut belum menyentuh ranah konsep politik bahasa di Indonesia, terutama dari perspektif sejarah (histori) dan kebijakan bahasanya, padahal konsep politik bahasa dalam kurun waktu 40 tahun (1975-2015) mengalami perubahan yang signifikan sehingga hal itu sangat berdampak terhadap kinerja pengembangan, pembinaan, dan pelindungan bahasa nasional, baik oleh pemerintah dalam hal ini Badan Pengembangan dan Pembinaan Bahasa (kini Badan Pengembangan Bahasa dan Perbukuan) maupun masyarakat umum, termasuk masyarakat akademisi (guru bahasa Indonesia, dosen bahasa Indonesia, dan mahasiswa Program Studi Pendidikan Bahasa dan Sastra Indonesia atau Sastra Indonesia).

Tulisan ini secara berturut-turut akan menguraikan metode penelitian yang digunakan. Kemudian beralih ke bagian hasil dan pembahasan mengenai kajian sejarah konsep politik bahasa tahun 1975, 1999, dan 2015 serta dampaknya terhadap kebijakan bahasa di Indonesia. Agar memudahkan pembaca, uraian pembahasan dilengkapi foto/gambar yang relevan. Terakhir, tulisan ini akan diakhiri dengan kesimpulan, ucapan terima kasih, dan daftar pustaka.

\section{METODE PENELITIAN}

Penelitian ini tergolong ke dalam jenis penelitian kualitatif deskriptif. Deskripsi merupakan gambaran ciri-ciri data secara akurat dan sesuai dengan sifat alamiah data itu sendiri. Data yang dianalisis, yaitu peristiwa munculnya konsep politik bahasa (nasional) di Indonesia dari tahun 1975 sampai dengan tahun 2015. Kemudian teknik analisis data yang digunakan adalah kajian isi (content analysis). Menurut Krippendorf (1980), kajian isi adalah teknik penelitian yang dimanfaatkan untuk menarik kesimpulan yang replikatif dan sahih dari data atas dasar konteksnya.

Langkah selanjutnya, peneliti melakukan penyusunan dan kategorisasi. Menurut Moleong (1988), kategorisasi merupakan langkah yang penting dan harus mengikuti aturan-aturan tertentu. Pertama, kategori harus berkaitan dengan tujuan penelitian. Kedua, kategori itu harus "tuntas", artinya setiap data dapat ditempatkan pada salah satu kategorinya. Ketiga, kategori harus "tidak saling bergantung", artinya tidak boleh ada satu pun isi data yang dapat masuk ke dalam lebih dari satu kategori. Keempat, kategori harus "bebas". Kelima, kategori harus diperoleh atas dasar prinsip klasifikasi tunggal.

Keabsahan data dalam penelitian ini dilakukan dengan dua konsep, yaitu konsep kesahihan (validitas) dan konsep keterandalan (reliabilitas). Dalam penelitian ini, peneliti menggunakan validitas semantik dan reliabilitas melalui cara baca dan kaji ulang. Untuk memperoleh data yang terpercaya, peneliti melakukan tiga cara, yaitu (1) ketekunan pengamatan, (2) triangulasi, dan (3) pengecekan teman sejawat.

Triangulasi dalam penelitian ini berupa teknik triangulasi sumber, metode, dan teori. Menurut Patton (lewat Moleong, 1988), triangulasi dengan sumber berarti membandingkan dan mengecek balik derajat kepercayaan sesuatu informasi yang diperoleh melalui waktu dan alat yang berbeda dalam metode kualitatif. Adapun teman sejawat dalam penelitian ini adalah Prof. Drs. Soeparno, dosen mata kuliah Sejarah dan Politik Bahasa Nasional pada Program Studi Pendidikan Bahasa dan Sastra Indonesia 
FKIP Universitas Ahmad Dahlan. Ia dipandang memiliki kemampuan yang baik di bidang sejarah bahasa Indonesia, terutama politik bahasa nasional dari tahun 1975 hingga tahun 2015.

\section{HASIL DAN PEMBAHASAN}

Bagian ini menguraikan hasil dan pembahasan sejarah konsep politik bahasa di Indonesia pada kurun waktu 40 tahun (1975-2015) dilengkapi foto-foto yang relevan. Secara berurutan, dibahas sejarah konsep politik bahasa versi tahun 1975, 1999, dan 2015, beserta dampaknya terhadap kebijakan bahasa di Indonesia.

\section{Seminar Politik Bahasa Nasional (1975)}

Tahun 1975 diselenggarakan Seminar Politik Bahasa Nasional (SPBN) di Jakarta, atau tepatnya pada tanggal 25-28 Februari 1975. Setahun sebelumnya telah diselenggarakan Praseminar Politik Bahasa Nasional di Jakarta pada tanggal 29-31 Oktober 1974 (Halim, 1984a). Jadi, SPBN tahun 1975 merupakan kelanjutan dari Praseminar Politik Bahasa Nasional tahun 1974. Adapun tujuan penyelenggaraan SPBN tahun 1975 terbagi atas tiga buah, yaitu (1) perencanaan dan perumusan isi kerangka dasar kebijaksanaan bahasa nasional, (2) perumusan dan penyusunan ketentuanketentuan dan garis-garis kebijaksanaan umum mengenai penelitian, pengembangan, pembakuan, dan pengajaran bahasa dan sastra, dan (3) penyusunan rencana umum pengembangan kebijaksanaan bahasa nasional. Hal itu sesuai dengan sambutan dari Kepala Pusat Pembinaan dan Pengembangan Bahasa, Departemen Pendidikan dan Kebudayaan, Amran Halim.

\section{Gambar 3. Amran Halim}



Di dalam SPBN itu disajikan dan dibahas sepuluh kertas kerja (paper), yaitu (1) "Fungsi dan Kedudukan Bahasa Indonesia" oleh Amran Halim, (2) "Ciri-Ciri Bahasa Indonesia Baku" oleh Anton M. Moeliono, (3) "Tata Cara Pembakuan dan Pengembangan Bahasa Indonesia" oleh Harimurti Kridalaksana, (4) "Pengajaran Bahasa Indonesia" oleh I Gusti Ngurah Oka, (5) "Fungsi dan Kedudukan Bahasa Daerah" oleh S. Wojowasito, (6) "Pengembangan Bahasa Daerah" oleh Ajip Rosidi, (7) "Pengajaran Bahasa Daerah" Tarwotjo, (8) "Inventarisasi Bahasa Daerah" oleh S. Effendi, (9) "Fungsi dan Kedudukan Bahasa Asing", dan (10) "Pengajaran Bahasa 
Asing" oleh Retmono. Kesepuluh kertas kerja di atas telah disajikan dan dibahas di dalam SPBN dan diterbitkan menjadi buku dengan judul Politik Bahasa Nasional 2 dieditori Amran Halim.

Sementara itu, konsep politik bahasa nasional versi SPBN tahun 1975 adalah kebijaksanaan nasional yang berisi perencanaan, pengarahan, dan ketentuan-ketentuan yang dapat dipakai sebagai dasar bagi pengolahan keseluruhan masalah kebahasaan. Masalah kebahasaan di Indonesia merupakan jaringan masalah yang dijalin oleh (1) masalah bahasa nasional, (2) masalah bahasa daerah, dan (3) masalah pemakaian dan pemanfaatan bahasa-bahasa asing tertentu di Indonesia. Pengolahan keseluruhan masalah bahasa ini memerlukan adanya satu kebijaksanaan nasional yang dirumuskan sedemikian rupa sehingga pengolahan masalah bahasa itu benar-benar berencana, terarah, dan menyeluruh. Singkat kata, konsep politik bahasa versi SPBN tahun 1975 lebih menitikberatkan pada aspek bahasa Indonesia, bahasa daerah, dan bahasa asing.

\section{Seminar Politik Bahasa (1999)}

Tahun 1999 diselenggarakan Seminar Politik Bahasa (SPB) di Cisarua, Bogor, Jawa Barat, pada tanggal 8-12 November 1999. Acara tersebut merupakan salah satu langkah tindak lanjut untuk meninjau kembali hasil SPBN tahun 1975 setelah melalui kurun waktu hampir 25 tahun. Selain itu, SPB tahun 1999 diselenggarakan untuk memperkuat putusan Kongres Bahasa Indonesia (KBI) VII tahun 1998 mengenai perlunya peningkatan kedudukan, fungsi, dan wewenang Pusat Pembinaan dan Pengembangan Bahasa (kini Badan Pengembangan dan Pembinaan Bahasa).

Dalam sambutannya, Kepala Pusat Bahasa, Hasan Alwi, menegaskan bahwa penyelenggaran SPB pada tanggal 8-12 November 1999 untuk menelaah dan merumuskan kembali hasil SPBN tahun 1975, sesuai dengan perkembangan masalah kebahasaan yang telah terjadi di Indonesia selama seperempat abad. Perbedaan antara SPBN tahun 1975 dan SPB tahun 1999 lebih bertumpu pada perubahan dalam hal intensitasnya, sesuai dengan keperluan dan tuntutan kelompok masyarakat terhadap bahasa Indonesia dalam berbagai ranah pemakaiannya. Perubahan itu, lanjut Hasan, akan terus berlangsung seirama dengan perkembangan linear dari setiap fungsi yang melekat pada bahasa Indonesia, baik dalam kedudukannya sebagai bahasa persatuan maupun sebagai bahasa negara.

\section{Gambar 4. Hasan Alwi}

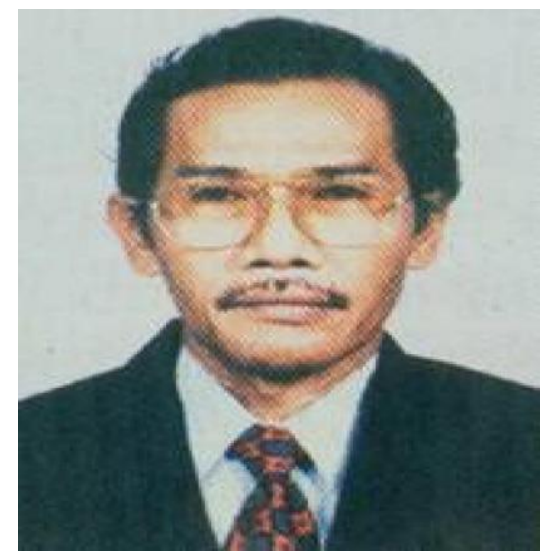


Di dalam SPB itu disajikan 13 makalah, yaitu (1) "Fungsi Politik Bahasa" oleh Hasan Alwi, (2) "Otoritarianisme dan Distorsi Bahasa" oleh Eep Saefulloh Fatah, (3) "Bahasa Daerah sebagai Sarana Peningkatan Pemahaman Kondisi Kebhinekaan dalam Ketunggalikaan Masyarakat Indonesia: Ke Arah Pemikiran dalam Mereposisi Fungsi Bahasa Daerah" oleh Mahsun, (4) "Kedudukan dan Fungsi Bahasa Asing" oleh Nuril Huda, (5) "Dinamika Sastra Indonesia dan Sastra Daerah" oleh Edi Sedyawati, (6) "Penelitian Bahasa dalam Kerangka Politik Bahasa" oleh Dédé Oetomo, (7) "Hal-Hal yang Dipertimbangkan dalam Menyusun Kebijakan Penelitian Sastra dan Pengajarannya" oleh Yus Rusyana, (8) "Pengajaran Bahasa Asing: Gambaran Nyata dan Beberapa Gagasan Kebijakan" oleh Fuad Abdul Hamied, (9) "Sarana Uji Kemahiran Berbahasa sebagai Salah Satu Prasarana Pembangunan Bangsa" oleh Sugiyono dan A. Latief, (10) "Peningkatan Mutu Pengajaran Bahasa" oleh Bambang Kaswanti Purwo, (11) "Pengajaran Sastra dan Pemasyarakatan Sastra" oleh Budi Darma, (12) "Bahasa Koran, Radio, dan Televisi Perlu Pembenahan Menyeluruh" oleh Djafar H. Assegaff, dan (13) "Pusat Pembinaan dan Pengembangan Bahasa dan Politik Bahasa Nasional" oleh Hans Lapoliwa.

Sementara itu, konsep politik bahasa versi SPB tahun 1999 adalah kebijakan nasional yang berisi pengarahan, perencanaan, dan ketentuan-ketentuan yang dapat dipakai sebagai dasar pengelolaan keseluruhan masalah kebahasaan dan kesastraan di Indonesia. Keseluruhan masalah itu merupakan jaringan masalah yang dijalin oleh (1) masalah bahasa dan sastra Indonesia, (2) masalah bahasa dan sastra daerah, dan (3) masalah bahasa asing di Indonesia. Pengelolaan keseluruhan masalah bahasa itu memerlukan adanya satu kebijakan nasional yang dirumuskan sedemikian rupa sehingga pengelolaan masalah bahasa-bahasa itu benar-benar berencana, terarah, dan menyeluruh. Singkat kata, konsep politik bahasa versi SPB tahun 1999 lebih menitikberatkan pada aspek bahasa dan sastra Indonesia, bahasa dan sastra daerah, dan bahasa asing.

Konsep politik bahasa nasional versi tahun 1975 dan politik bahasa versi tahun 1999 merupakan penjabaran dari Pasal 36 ayat (1) Undang-Undang Dasar Negara Republik Indonesia Tahun 1945, yang berbunyi, "Bahasa Negara ialah Bahasa Indonesia." Hal ini sejalan dengan pemikiran Sudaryanto (2018) bahwa fase bahasa Indonesia sebagai bahasa resmi negara bermuara dari Pasal 36 UUD 1945. Kemudian hal itu diikuti dengan serangkaian kebijakan dan peristiwa bahasa, seperti penerapan Ejaan yang Disempurnakan (EYD) pada tahun 1972, penyelenggaraan Kongres Bahasa Indonesia III pada tahun 1978, dan amandemen UUD 1945 pada tahun 2000-an dan memunculkan Pasal 36C ayat (1) yang berbunyi, "Ketentuan lebih lanjut mengenai Bendera, Bahasa, dan Lambang Negara, serta Lagu Kebangsaan diatur dengan undang-undang."

\section{Seminar Politik Bahasa (2015)}

Tahun 2015 diselenggarakan Seminar Politik Bahasa (SPB) di Jakarta pada tanggal 3-6 Juni 2015 dengan tema "Mengawal Bangsa Besar dengan Berawal Bahasa”. SPB tahun 2015 merupakan forum pemutakhiran kebijakan nasional kebahasaan atas rumusan politik yang dihasilkan dari dua seminar terdahulu yang diselenggarakan pada tahun 1975 dan 1999. Seminar yang ketiga ini (jika Praseminar Politik Bahasa Nasional pada tahun 1974 tidak dihitung) dihadiri 250 orang peserta 
yang terdiri atas pengambil kebijakan, pakar, dosen, guru, sastrawan, budayawan, pemuda, peminat, serta pemerhati bahasa dan sastra. SPB tahun 2015 dibuka oleh Kepala Badan Pengembangan dan Pembinaan Bahasa, Mahsun.

\section{Gambar 5. Mahsun}

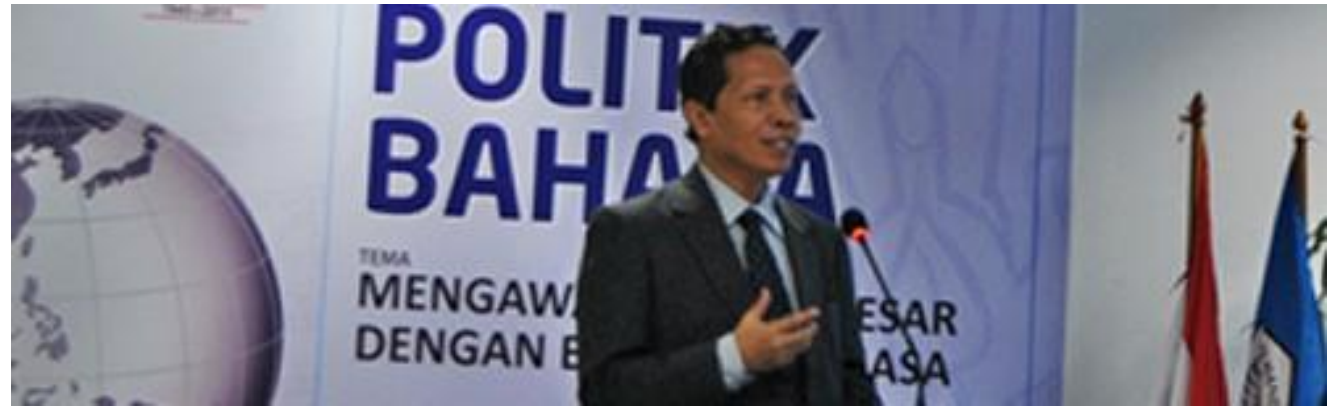

Gambar 6. Publikasi Seminar Politik Bahasa Tahun 2015

Badan Pengembangan dan Pembinaan Bahasa

Kementerian Pendidikan dan Kebudayaan

\section{SEMINAR POLTTK BAHASA}

"Mengawal Bangsa Besar dengan Berawal Bahasa"

\section{PENGUMUMAN}

Dalam SPB tahun 2015 telah dibahas delapan makalah sidang pleno dengan subtema-subtema, seperti merajut kebinekaan bahasa sebagai pemerkukuh ikatan kebangsaan, strategi kebahasaan untuk memperkukuh ikatan negeri bahari, perspektif linguistik diakronis dan ikatan kebangsaan, bahasa Melayu sebagai pendukung internasionalisasi bahasa Indonesia, penguatan wawasan kebangsaan melalui bahasa sebagai tantangan dunia global, identifikasi konflik dan ancaman disintegrasi melalui gejala kebahasaan, bahasa-bahasa di Indonesia wilayah timur sebagai penopang internasionalisasi bahasa Indonesia, dan penegakan integritas bangsa melalui layanan publik nasional dan internasional.

Selanjutnya, SPB tahun 2015 memandang bahwa pemahaman terhadap kebebabasan pada era reformasi dan globalisasi telah menyebabkan karut-marutnya penggunaan bahasa di ruang publik dan menimbulkan dugaan terjadinya pembiaran atas kekarut-marutan itu secara sistematis. Oleh karena itu, dipandang penting pengambilan langkah-langkah pembinaan, selain langkah-langkah pengembangan dan pelindungan bahasa serta pengembangan strategi dan diplomasi kebahasaan untuk menjaga keseimbangan antara upaya penciptaan keseragaman dan pengelolaan keberagaman bahasa di Indonesia, serta untuk memajukan bahasa Indonesia sebagai salah satu bahasa 
internasional, terutama di kawasan Asia Tenggara, guna membangkitkan kembali semangat Sumpah Pemuda 1928. Singkat kata, konsep politik bahasa versi SPB tahun 2015 lebih menitikberatkan pada peningkatan fungsi bahasa Indonesia menjadi bahasa internasional, sejalan dengan Pasal 44 ayat (1) Undang-Undang Nomor 24 Tahun 2009 tentang Bendera, Bahasa, dan Lambang Negara, serta Lagu Kebangsaan, yang berbunyi, "Pemerintah meningkatkan fungsi Bahasa Indonesia menjadi bahasa internasional secara bertahap, sistematis, dan berkelanjutan." Selanjutnya diikuti dengan terbitnya Peraturan Pemerintah Republik Indonesia Nomor 57 Tahun 2014 tentang Pengembangan, Pembinaan, dan Pelindungan Bahasa dan Sastra, serta Peningkatan Fungsi Bahasa Indonesia, khususnya Bab VII Pasal 31 ayat (1), (2), (3), dan (4).

Pasal 31 ayat (1) berbunyi, "Peningkatan fungsi Bahasa Indonesia menjadi bahasa internasional bertujuan untuk menunjukkan jati diri dan meningkatkan daya saing bangsa." Pasal 31 ayat (2) berbunyi, "Peningkatan fungsi Bahasa Indonesia menjadi bahasa internasional sebagaimana dimaksud pada ayat (1) dilakukan melalui: a. penggunaan Bahasa Indonesia di forum internasional; b. pengembangan program pengajaran Bahasa Indonesia untuk orang asing; $c$. peningkatan kerja sama kebahasaan dan kesastraan dengan pihak luar negeri; $d$. pengembangan dan pemberdayaan pusat pembelajaran Bahasa Indonesia di luar negeri; dan atau e. upaya lain sesuai dengan ketentuan peraturan perundang-undangan." Pasal 31 ayat (3) berbunyi, "Peningkatan fungsi Bahasa Indonesia menjadi bahasa internasional sebagaimana dimaksud pada ayat (2) dikoordinasi oleh Badan." Terakhir, Pasal 31 ayat (4) berbunyi, "Peningkatan fungsi Bahasa Indonesia menjadi bahasa internasional sebagaimana dimaksud pada ayat (3) ditetapkan oleh Menteri sebagai kebijakan nasional."

\section{KESIMPULAN}

Berdasarkan uraian hasil dan pembahasan di atas, dapat ditarik kesimpulan sebagai berikut. Indonesia telah memiliki konsep politik bahasa yang selalu diperbaharui dalam kurun waktu tertentu. Konsep politik bahasa nasional versi Seminar Politik Bahasa Nasional tahun 1975 lebih menitikberatkan pada aspek bahasa Indonesia, bahasa daerah, dan bahasa asing, sedangkan konsep politik bahasa versi Seminar Politik Bahasa tahun 1999 lebih menitikberatkan pada aspek bahasa dan sastra Indonesia, bahasa dan sastra daerah, dan bahasa asing. Sementara itu, konsep politik bahasa versi Seminar Politik Bahasa tahun 2015 lebih menitikberatkan peningkatan fungsi bahasa Indonesia menjadi bahasa internasional. Selanjutnya, konsep politik bahasa versi tahun 1975 dan 1999 merupakan penjabaran dari Pasal 36 ayat (1) UUD 1945, sedangkan konsep politik bahasa versi tahun 2015 penjabaran dari UU Nomor 24 Tahun 2009 tentang Bendera, Bahasa, dan Lambang Negara, serta Lagu Kebangsaan dan PP Nomor 57 Tahun 2014 tentang Pengembangan, Pembinaan, dan Pelindungan Bahasa dan Sastra, serta Peningkatan Fungsi Bahasa Indonesia.

\section{UCAPAN TERIMA KASIH}

Penulis mengucapkan terima kasih kepada mitra bestari (reviewer) dan redaksi jurnal Aksis yang telah mendukung penerbitan artikel ilmiah ini. 


\section{REFERENSI}

Abdullah, I. (2003). Politik Bhinneka Tunggal Ika dalam keragaman budaya Indonesia. Jurnal Masyarakat dan Budaya, 5(2), 1-13.

Alwi, H. (2000). Bahasa Indonesia: Pemakai dan pemakaiannya. Jakarta: Departemen Pendidikan Nasional.

Alwi, H. \& Sugono D. (2011). Politik bahasa: Risalah seminar politik bahasa. Jakarta: Badan Pengembangan dan Pembinaan Bahasa Kementerian Pendidikan dan Kebudayaan.

Assapari, M. M. (2014). Eksistensi bahasa Indonesia sebagai bahasa nasional dan perkembangannya di era globalisasi. Prasi, 9(18), 29-37.

Aziz, A. L. (2014). Penguatan identitas bahasa Indonesia sebagai lambang identitas nasional dan bahasa persatuan jelang penerapan Masyarakat Ekonomi ASEAN (MEA) 2015. Jurnal Studi Sosial, 6(1), $14-20$.

Dardjowidjojo, S. (1998). Strategies for a succesful national language policy: The Indonesian case. International Journal of the Sociology of Language, 130(1), $35-48$.

Halim, A. (ed.). (1984a). Politik bahasa nasional 1. Jakarta: PN Balai Pustaka.

Halim, A. (ed.). (1984b). Politik bahasa nasional 2. Jakarta: PN Balai Pustaka.

Jalal, M. (2001). Nasionalisme bahasa Indonesia dan kompleksitas persoalan sosial dan politik. Masyarakat, Kebudayaan, dan Politik, 14(1), 81-92.

Kridalaksana, H. (2011). Kamus linguistik edisi keempat. Jakarta: Gramedia Pustaka Utama.

Krippendorf, K. (1980). Content analysis: Its a methodology. Beverly Hills-New York: Sage Publications.

Moleong, L. J. (1988). Metode penelitian kualitatif. Jakarta: Depdikbud.

Mulyana, A. T. (2018). Isu-isu kritis kebijakan bahasa dan pengajaran bahasa. Biormatika: Jurnal Ilmiah Fakultas Keguruan dan Ilmu Pendidikan, 4(01), 1-7.

Mutmainah, S. (2018). Nilai Islam dan nilai kebangsaan dalam pembelajaran bahasa Indonesia. Falasifa: Jurnal Studi Keislaman, 9(1), 69-84.

Muqri, M., Sugono, D., \& Khairah, M. (2016). Penggunaan bahasa pada papan nama di ruang publik jalan protokol Jakarta. Arkhais: Jurnal Ilmu Bahasa dan Sastra Indonesia, 7(2), 57-64. 
Pastika, I. W. (2012). Pengaruh bahasa asing terhadap bahasa Indonesia dan bahasa daerah: Peluang atau ancaman? Jurnal Kajian Bali, 2(2), 141-164.

Purwahida, R. (2018). Problematika Pengembangan Modul Pembelajaran Baca Tulis Anak Usia Sekolah Dasar. Aksis: Jurnal Pendidikan Bahasa dan Sastra Indonesia 2(1). 118-134. doi: doi.org/10.21009/AKSIS.020108

Rahayu, A. P. (2015). Menumbuhkan bahasa Indonesia yang baik dan benar dalam pendidikan dan pengajaran. Jurnal Paradigma, 2(1), 1-15.

Santoso, B. (2008). Bahasa dan identitas budaya. Sabda: Jurnal Kajian Kebudayaan, $1(1), 44-49$.

Sartini, N. W. (2014). Revitalisasi bahasa Indonesia dalam konteks kebahasaan. Masyarakat, Kebudayaan, dan Politik, 27(4), 206-210.

Sihombing, R., Wisnaeni, F., \& Saraswati, R. (2017). Indonesia nomor 24 Tahun 2009 tentang bendera, bahasa, dan lambang negara, serta lagu kebangsaan (Studi penggunaan bahasa Indonesia di bangunan gedung fungsi usaha yang ada di Kota Semarang). Diponegoro Law Journal, 6(2). 1-10.

Sudaryanto. (2017). Kamus umum bahasa dan ilmu bahasa. Yogyakarta: Samudra Biru.

Sudaryanto. (2018). Tiga fase perkembangan bahasa Indonesia (1928-2009): Kajian linguistik historis. Aksis: Jurnal Pendidikan Bahasa dan Sastra Indonesia, 2(1), $1-16$.

Sudrama, K. \& Yadnya, I. B. P. (2017). Dilema multilingualisme dan implikasinya terhadap perencanaan bahasa. Retorika: Jurnal Ilmu Bahasa, 1(1), 94-107.

Suhartatik. (2018). Makna Leksikal Bahasa Madura Keadaan Alam Nelayan di Pesisir Kepulauan Sumenep. Aksis: Jurnal Pendidikan Bahasa dan Sastra Indonesia 2(1). 107-126. doi: doi.org/10.21009/AKSIS.020107

Tilaar, H. A. R. (2017). Pendidikan untuk mengembangkan identitas bangsa. Abad: Jurnal Sejarah, 1(1), 25-33.

Wahyuni, S. (2018). Upaya meningkatkan hasil belajar dalam menanggapi isi laporan melalui model cooperative learning pembelajaran kepala bernomor struktur (NHT) pada peserta didik kelas VIIIF. Jurnal Ilmiah Edunomika, 2(01, 165-174.

Wijana, I. D. P. (2018). Pemertahanan dan pengembangan bahasa Indonesia. Widyaparwa, 46(1), 91-98. 